\title{
Juvenile Individuals of Opahs (Lampridae) from the Atlantic and Pacific Oceans. Notes on the Systematics and Distribution of Opahs, Including the Description of a New Subgenus, Paralampris subgen. nov.
}

\author{
E. I. Kukuev* \\ Atlantic Research Institute of Fisheries and Oceanography, Kaliningrad, Russia \\ *e-mail: efi-kukuev@yandex.ru \\ Received March 6, 2020; revised July 14, 2020; accepted July 14, 2020
}

\begin{abstract}
Juvenile specimens of opahs (Lampridae) from the Southwest Atlantic, southeastern Pacific Ocean, and Gulf of Guinea are described. A taxonomic review of the composition of the family Lampridae is carried out, taking into account the recent revision of opah species of the genus Lampris and our own data. A new subgenus, Paralampris subgen. nov., has been identified.
\end{abstract}

Keywords: Lampridae, Lampris, juvenile specimens, description, systematics, distribution, Paralampris subgen. nov.

DOI: $10.1134 / \mathrm{S} 0032945221020089$

It was previously believed that the opah family (Lampridae), belonging to the order Lampridiformes, includes only one genus with a single species, Lampris guttatus (Brünnich, 1788); all the later described species from different areas were considered as its synonyms (Lindberg, 1971; Palmer, 1973). The validity of the species L. immaculatus Gilchrist, 1904, described from the coast of South Africa, was restored based on its differences from L. guttatus in the morphology and type of range (Parin and Kukuev, 1983). Recent genetic studies have shown a heterogeneity of the species $L$. guttatus in different parts of its range and suggested a collective nature of this species (Hyde et al., 2014). This assumption has been confirmed by the revision of the genus Lampris (Underkoffler et al., 2018), during which the validity of $L$. lauta Lowe, 1838 was restored and three new species, $L$. incognitus, L. megalopsis, and L. australensis Underkoffler, Luers, Hyde et Craig, 2018, were described. The material for this revision included only large fish: individuals studied in the fishing and sale site at fish auctions in the Honolulu port, as well as a few museum specimens in the form of stuffed animals and pictures and figures from different publications. While analyzing this material, the authors noted that opahs were rather rare in museum collections and catches generally contained large specimens and very rarely included fry and juvenile individuals due to the high nutritional value and high cost of these species. For this reason, their studies do not provide any description of young and juvenile specimens of new species, as well as data on their age-related variability.

This publication describes juvenile opah specimens from the Southwest Atlantic (SWA), southeastern Pacific Ocean (SWPO), and Gulf of Guinea. Based on the recent revision of opahs of the genus Lampris (Underkoffler et al., 2018) and our own data, we carried out a taxonomic review of the composition of the family Lampridae, including the description of the new subgenus, Paralampris subgen. nov.

\section{MATERIALS AND METHODS}

The study material included five juvenile opah specimens from the collection of the Atlantic Research Institute of Fisheries and Oceanography (AtlantNIRO). The data on the studied specimens are given during the description of the corresponding species. We also studied the prepared shoulder girdles of adult individuals from the collections of the AtlantNIRO (L. guttatus, TL $900 \mathrm{~mm}$, the Atlantic coast of the United States) and Zoological Museum of the Moscow State University (L. immaculatus ZMMU no. P-16034, SL $820 \mathrm{~mm}$, the Scotia Sea, South Georgia).

This paper uses the following notations: $T L$, total length, $S L$, standard length, $H$, maximum body depth, $c$, head length, $o$, horizontal eye diameter; $a D, a P, a V$, and $a A$, antedorsal, antepectoral, anteventral, and anteanal distances; $V-A$, distance between the ventral 
Table 1. Plastic and meristic features of juvenile opah specimens of the genus Lampris

\begin{tabular}{|c|c|c|c|c|c|}
\hline \multirow{2}{*}{ Feature } & \multicolumn{3}{|c|}{ L. australensis } & \multicolumn{2}{|c|}{ L. immaculatus } \\
\hline & \multicolumn{2}{|c|}{ Southeastern Pacific } & Gulf of Guinea & Southeastern Pacific* & Southwest Atlantic \\
\hline$T L, \mathrm{~mm}$ & 370 & 125 & 90 & 140 & 150 \\
\hline$S L, \mathrm{~mm}$ & 310 & 120 & 82 & 115 & 120 \\
\hline & \multicolumn{5}{|c|}{ in D \% SL } \\
\hline$H$ & 68.0 & 66.7 & 73.3 & 61.0 & 65.0 \\
\hline$c$ & 32.2 & 29.6 & 28.5 & 33.4 & 33.3 \\
\hline$o$ & 9.6 & 10.0 & 12.1 & 8.4 & 8.3 \\
\hline$a D$ & 33.8 & 35.0 & 32.3 & 34.0 & 35.0 \\
\hline$a P$ & 30.6 & 33.3 & 35.7 & 32.0 & 35.0 \\
\hline$a V$ & 44.8 & 53.8 & 47.6 & 56.5 & 66.6 \\
\hline$a A$ & 58.6 & 69.2 & 52.2 & 69.5 & 75.0 \\
\hline$P-V$ & 5.0 & 7.6 & 6.0 & 24.5 & 20.0 \\
\hline$V-A$ & 9.6 & 9.5 & 8.7 & 7.3 & 8.3 \\
\hline$L D$ & 54.8 & 50.0 & 61.0 & 58.4 & 62.5 \\
\hline$L A$ & 44.1 & 41.6 & 46.3 & 32.0 & 37.5 \\
\hline \multirow[t]{2}{*}{$L V$} & 64.5 & 25.0 & 60.9 & 19.2 & 21.9 \\
\hline & \multicolumn{5}{|c|}{ Meristic features } \\
\hline$D$ & 49 & 52 & $\sim 50^{* *}$ & 52 & 50 \\
\hline$A$ & 39 & 38 & 38 & 38 & 35 \\
\hline V & 13 & 12 & 12 & 12 & 12 \\
\hline$P$ & 24 & 25 & 22 & 24 & 24 \\
\hline sp.br. & $17^{* * *}$ & 15 & 17 & 13 & 13 \\
\hline Spots & Available & Available & Available & Absent & Absent \\
\hline
\end{tabular}

* According to Parin and Kukuev, 1983; ** the fin is damaged; *** the marginal rakers are nodular; see the notations of the features in the MATERIALS AND METHODS section.

fins and anal fin, $P-V$, distance between the pectoral and ventral fins, $L D$, length of the dorsal fin base, $L A$, length of the anal fin base, $L V$, length of ventral fins; $D, A, V$, and $P$, numbers of rays in the dorsal, anal, pelvic, and pectoral fins, respectively, sp.br., number of gill rakers on the 1st gill arch. All distances were measured between the verticals in the straight line.

\section{RESULTS AND DISCUSSION \\ Lampris australensis Underkoffler, Luers, Hyde et Craig, 2018}

The material includes three specimens: $T L 125 \mathrm{~mm}$, SL $120 \mathrm{~mm}$, SWPO 522' S, 94 $\mathrm{W}$, 1980, Kulikovo Pole Freezer Trawler, collected by I.I. Konovalenko; $T L 370 \mathrm{~mm}, S L 310 \mathrm{~mm}$, SWPO, $40^{\circ} \mathrm{S}, 85^{\circ} \mathrm{W}$, December 1979, collected by G.K. Miloradov; and $T L$ $90 \mathrm{~mm}, S L 82 \mathrm{~mm}$, the Gulf of Guinea, 1978, collected by A.R. Boltachev.

Description. D 49-52 [50-52 $]^{1}, A$ 38-39 [40-42], $P$ 22-25 [22-23], $V$ 12-13 [13-15], sp.br. 15-17 [-]. Dorsal profile of head convex. Head length

\footnotetext{
${ }^{1}$ Here and elsewhere: the values for the features according to Underkoffler et al., 2018 are in square brackets.
}

3.1-3.5 [2.8] times in $S L$, head depth 1.8-2.5 [2.3] times in $S L$; eye diameter 8.3-10.4 [12.5] times in $S L$, 2.4-3.4 [5.2] times in c. Body depth 1.4-1.5 [1.4] times in $S L$ (Table 1).

Ventral fins on vertical through end of pectoral fin base; this vertical is along the middle of the body in specimens with $S L 120 \mathrm{~mm}$ (Fig. 1a) and $82 \mathrm{~mm}$ (Fig. 1b) and anterior to the middle of the body in specimens with $S L 310 \mathrm{~mm}$ (Fig. 2). Length of dorsal fin base 1.6-2.0 times in $S L$ and length of anal fin base 2.22.4 times in $S L ; P-V$ 5.0-7.6\% SL, $V-A$ 8.7-9.6\% $S L$. The elongated rays in the pelvic fins of one specimen $(S L 120 \mathrm{~mm})$ are $25 \% S L$; the rays in the pelvic fins of the other specimens are very long ( $L V$ 60.9$64.5 \% S L)$; they reach the caudal fin in individuals with $S L 310 \mathrm{~mm}$. The color of the specimens fixed in formalin is brown; light round spots clearly visible on body; their diameter as large as diameter of eye pupil. Fins yellowish.

With respect to the main meristic and plastic features, all the three studied specimens meet the description of L. australiensis; however, they differ in a deeper body and a larger eye diameter, which can be explained by the age-related variability (Oelschlager, 1974; Parin and Kukuev, 1983). Catches of L. austral- 
(a)

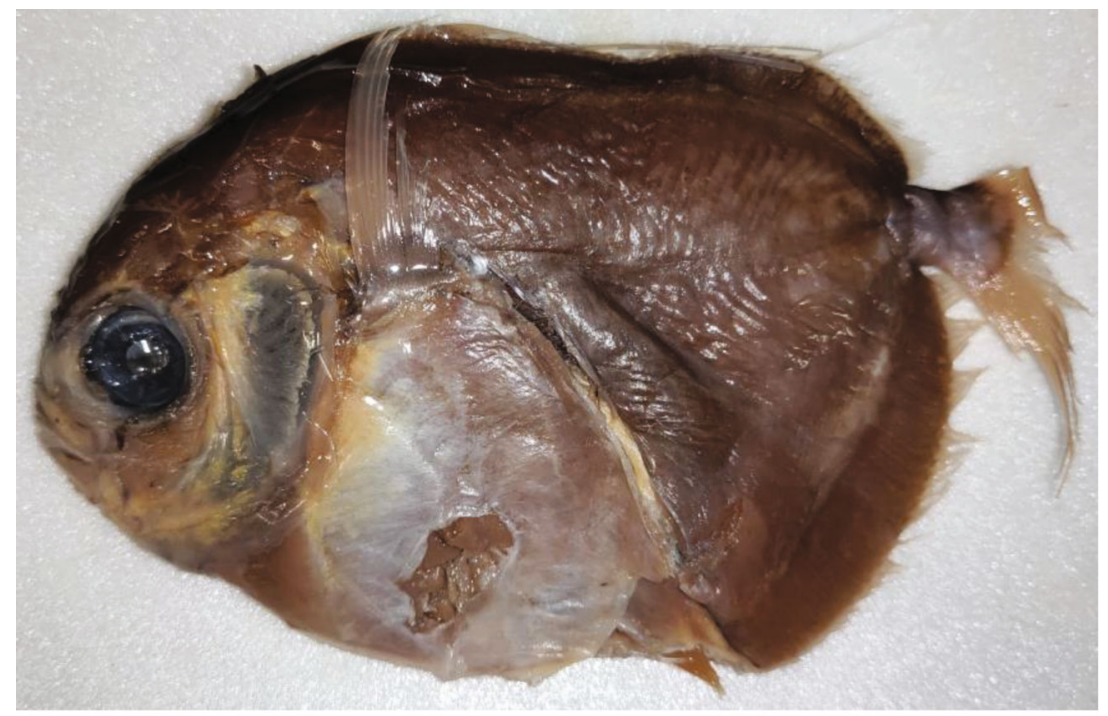

(b)

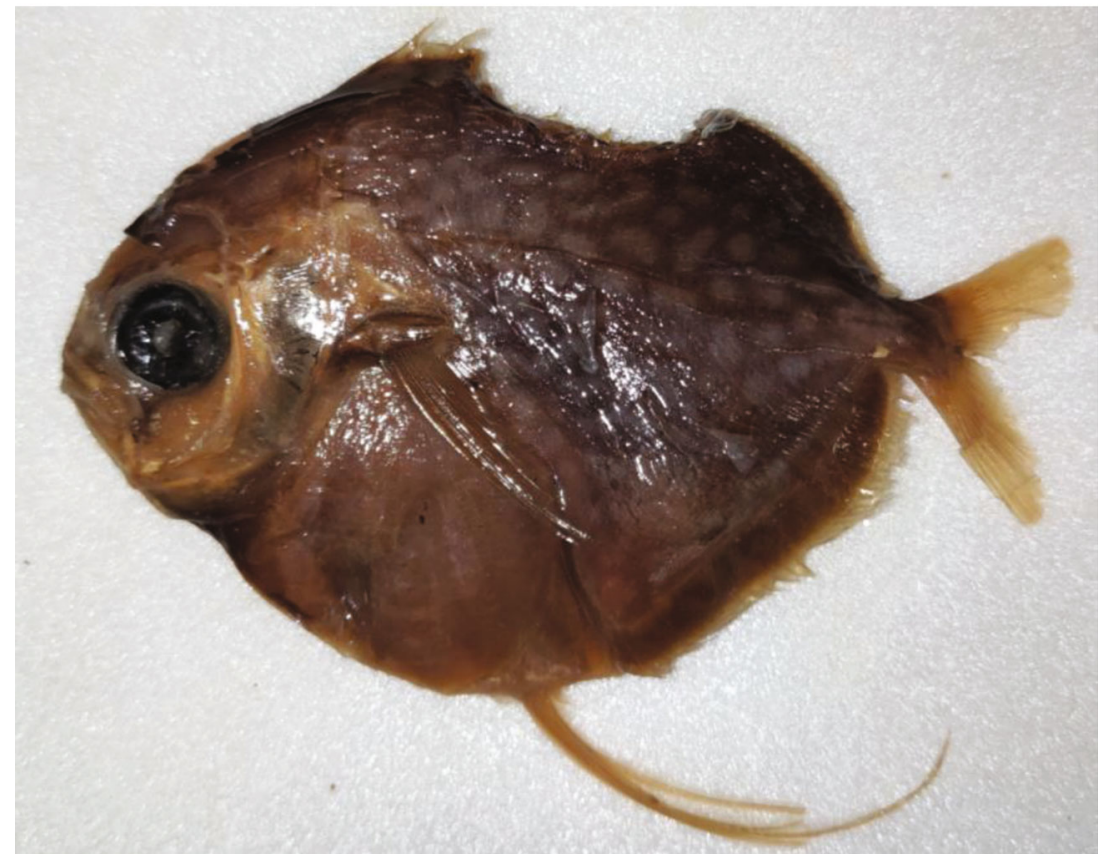

Fig. 1. Lampris australensis: (a) $S L 120 \mathrm{~mm}$, the southeastern Pacific Ocean; (b) $S L 82 \mathrm{~mm}$, the Gulf of Guinea.

ensis to the north of its main range are probably explained by its transport by currents.

\section{Lampris immaculatus Gilchrist, 1904}

The material includes one specimen: $T L 150 \mathrm{~mm}$, $S L 120 \mathrm{~mm}$, the open part of the Falkland-Patagonia area, 56 $50^{\prime} \mathrm{S}, 56^{\circ} 20^{\prime} \mathrm{W}$, depth $565 \mathrm{~m}$, August 24, 1985, Large Refrigerator Trawler Gizhiga, cruise no. 27, collected by V.V. Konstantinov.

D e s c ri p ti o n. $D 50, P 24, A 35, V 12$, sp.br. 13. Upper profile of head moderately convex. Head length
3.3 times in $S L$, head depth slightly more than 2 times in $S L$; eye diameter 12 times in $S L, 4$ times in c. Body depth 1.5 times in $S L$ (Table 1, Fig. 3a). Ventral fins distinctly behind vertical through end of pectoral fin base, noticeably behind middle of body; $P-V 20 \% S L$, $V-A 8.3 \% S L$. Length of dorsal fin base 1.6 times in $S L$ and length of anal fin base 2.6 times in $S L$. Rays in ventral fin slightly elongated ( $L V 21.9 \% S L$ ). Color of fixed specimen brown without spot traces. This specimen from the SWA meets the description of L. immaculatus juveniles from the SWPO (Table 1, Fig. 3b) (Parin and Kukuev, 1983) and belongs to this species. 
(a)

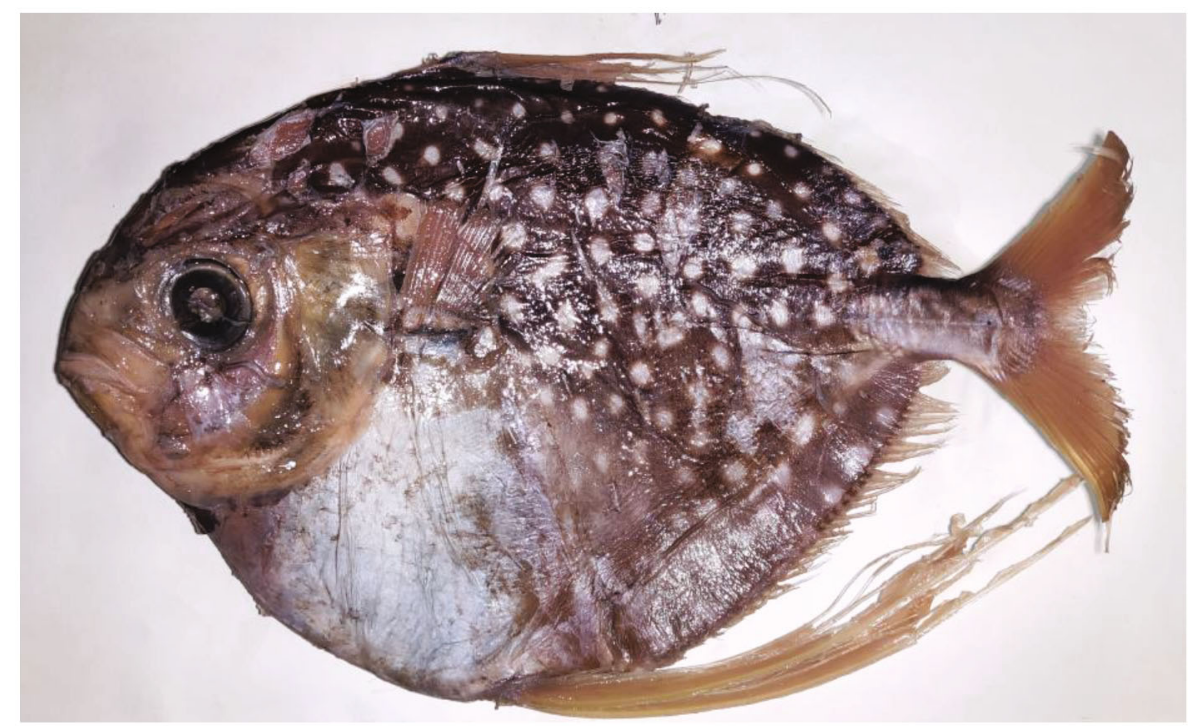

(b)

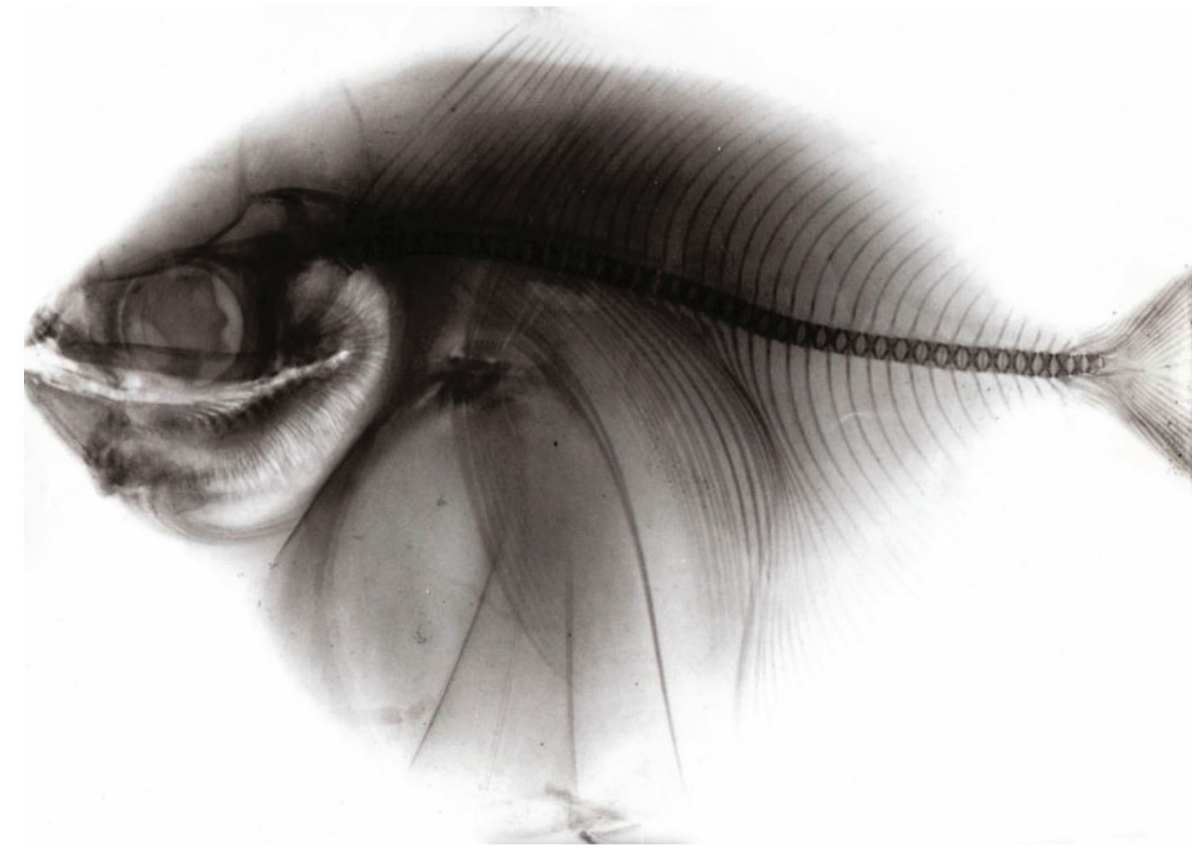

Fig. 2. (a) Lampris australensis and (b) its X-ray pattern. $S L 310 \mathrm{~mm}$, the southeastern Pacific Ocean.

\section{Notes on the Systematics of Opahs, Including the Description of the New Subgenus}

Many epi- and mesopelagic species have wide circumglobal ranges in the tropical zone of the World Ocean. However, recent studies have shown that species with these ranges are groups of species-rank related taxa, which differ in a small set of features (Parin, 1988). This also concerns the circumtropical species $L$. guttatus. According to the latest revision of the genus Lampris based on genetic and morphological analyzes, the family Lampridae includes six species (Hyde et al., 2014; Underkoffler et al., 2018). The name L. guttatus is reserved only for the North Atlantic population, the range of which is related to the subtropical and temperate waters of the North Atlantic, including the Mediterranean Sea. It should be noted that a similar type of range is recorded for Atlantic bluefin tuna Thunnus thynus, Atlantic mackerel Scomber scombrus, and drift fish Cubiceps gracilis (Collette and Nauen, 1983; Agafonova and Kukuev, 1990). The authors restored the validity of the species L. lauta by limiting its range to the North Atlantic (the Azores and Canary Islands and Mediterranean Sea). It can be noted that this kind of endemism is illogical for 
(a)

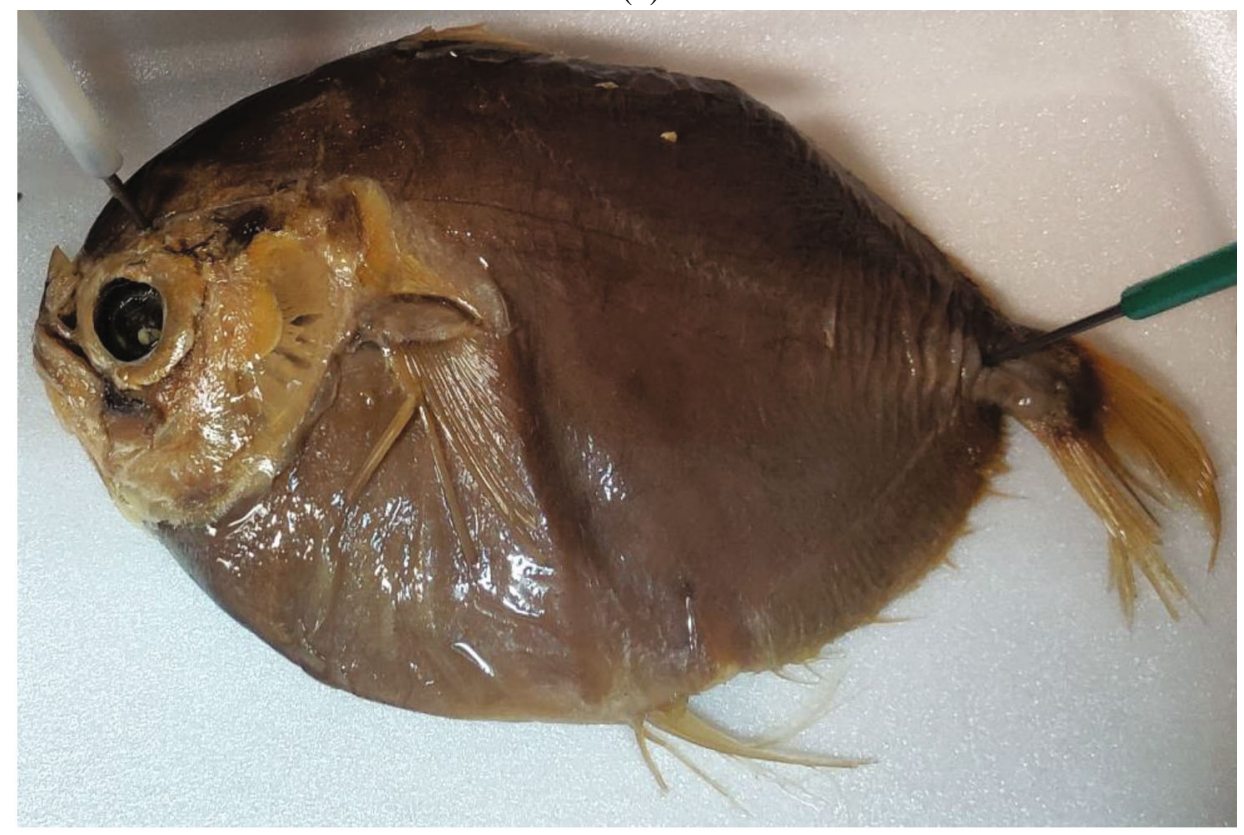

(b)

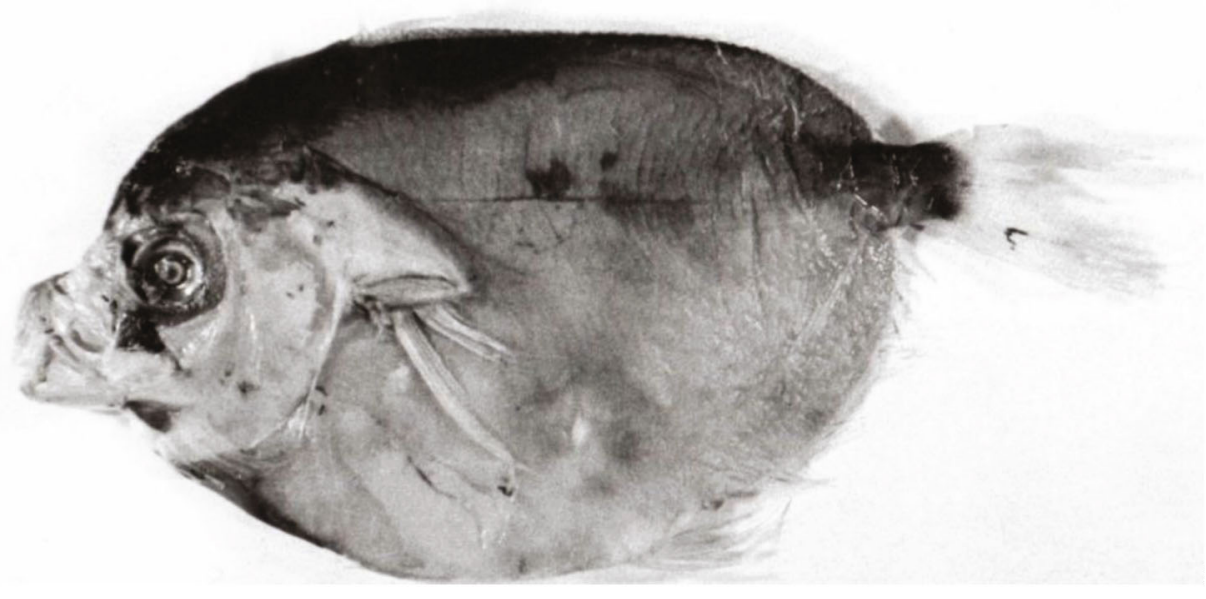

Fig. 3. Lampris (Paralampris) immaculatus: (a) SL $120 \mathrm{~mm}$, the southwestern Atlantic; (b) SL $115 \mathrm{~mm}$, the southeastern Pacific Ocean.

the nektonic pelagic species. Presumably, the further accumulation of factual material will show a wider range of this species. The authors of the revision also described three new species. L. incognitus was identified in the northern part of the Pacific Ocean in temperate and subtropical waters. The same type of range among nektonic fishes is characteristic of the Pacific population of bluefin tuna. The second new species, L. megalopsis, has a wider circumtropical range. According to the authors, the spread of the third new species, L. australensis, is determined by the temperate and subtropical waters of the Southern Hemisphere (notal-subtropical range). This range is typical for nektonic mackerel fishes (Scombridae), such as Thun- nus maccoyii and Gasterochiasma melampus (Collette and Nauen, 1983), as well as Agrostichthysparkeri from the family Regalecidae (Trunov and Kukuev, 2005).

The studied juvenile specimens of opahs from the SWPO, SWA, and Gulf of Guinea were determined as L. australensus and L. immaculatus according to the revision keys (Underkoffler et al., 2018). The data obtained supplement the characteristics of these species with some features (e.g., the number of gill rakers). It should be noted that the characteristic features of the external structure and proportions of adult individuals of the species, including the size and spread of spots, are observed in L. australensis juveniles as early as their $S L$ reaches $\sim 100 \mathrm{~mm}$ (Figs. 1, 2a). The quite 


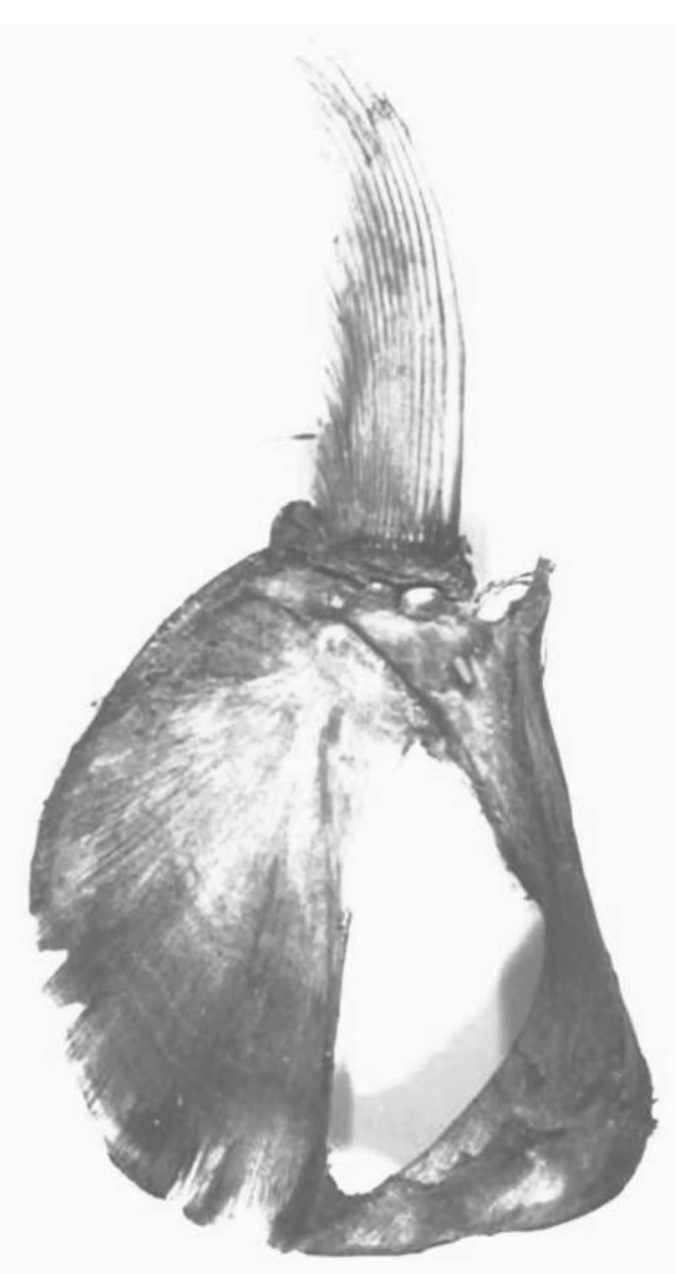

Fig. 4. Shoulder girdle of Lampris guttatus with $T L 900 \mathrm{~mm}$, the North Atlantic.

large eye diameter in juvenile L. australiensis specimens (comparable to that indicated for the adult individuals of the circumtropical species L. megalopsis), as well as the greater body depth than that in adult individuals, are a manifestation of the age-related variability in opah fishes, which was also noted earlier (Oelschlager, 1974). The finding of L. australiensis fry in the near-equatorial waters of the Pacific and Atlantic oceans in the direction of the Humboldt and Benguela currents suggests a wider distribution of this species owing to the ability of its larvae and fry to drift.

With respect to a number of features, the specimen of L. immaculatus with $S L 120 \mathrm{~mm}$ from the SWA fully meets the description of the specimen with $S L 115 \mathrm{~mm}$ from the SWPO (Parin and Kukuev, 1983). At the same time, the reliable features differentiating L. immaculatus juveniles from other species are the position of the ventral fins with respect to the pectoral fins, as well as the smaller eye diameter and the absence of spots on the body, which are clearly visible in other species even at $S L \sim 100 \mathrm{~mm}$.
The validity of $L$. immaculatus was restored by comparing it with circumtropical L. guttatus according to the main features, such as body depth and shape, the position of the ventral fins with respect to the pectoral ones, the structure of the shoulder girdle, and the absence/presence of spots on the body (Parin and Kukuev, 1983). The last revision (Underkoffler et al., 2018) made it quite obvious that these features were opposed not only for L. guttatus (which proved to be a collective species), but also for all the other five described and restored species. In this case, it can be said that L. immaculatus belongs to a particular subgenus. Indeed, L. immaculatus is characterized by a terete bomb-shaped body, unlike the strongly compressed dolabriform body in all other five species, as well as by a functionally less specialized skeleton of the shoulder girdle (Figs. 4, 5) and, consequently, by other morphofunctcional capacities (Kukuev and Nigmatullin, 2008). As shown above, these features are observed in juveniles even at $S L \sim 100 \mathrm{~mm}$. It can be assumed that less specialized L. immaculatus is an ancient ancestral form that was displaced to the southern periphery of the range and then formed the Subantarctic and Antarctic ranges (Andriyashev, 1988; Kukuev, 2014; Kukuev, 2014). All these data make it reasonable to differentiate a new subgenus, Paralampris subgen. nov., with the type species L. immaculatus in the genus Lampris nov.

\section{Genus Lampris Retzius, 1799}

Type species: L. guttatus (Brünnich, 1788); the North Sea.

The main features of the genus coincide with the characteristics of the family Lampridae (Lindberg, 1971; Nelson, 2009). The genus Lampris includes two subgenera, Lampris and Paralampris.

\section{Subgenus Lampris Retzius, 1799}

Type species: L. guttatus (Brünnich, 1788); the North Sea.

D i a g n o s i s. Body deep, laterally strongly compressed, dolabriform, with cutting edge (keel) on belly. Ventral fins on vertical from end of pectoral fin base within shoulder girdle; $P-V 5-16 \% S L$. External plate of coracoid in shoulder girdle skeleton strongly developed and strongly elongated in the dorsoventral direction; its width $\sim 50 \%$ its height (Figs. $2 \mathrm{~b}, 4,5 \mathrm{c}$ ). Light spots well defined and visible on body in juveniles at $S L<100 \mathrm{~mm}$.

The subgenus includes five structurally similar species living in tropical, subtropical, and temperate waters of the World Ocean.

\section{Subgenus Paralampris Kukuev subgen. nov.}

Ty p e spe ci es: L. immaculatus Gilchrist, 1904; South Africa. 
(a)

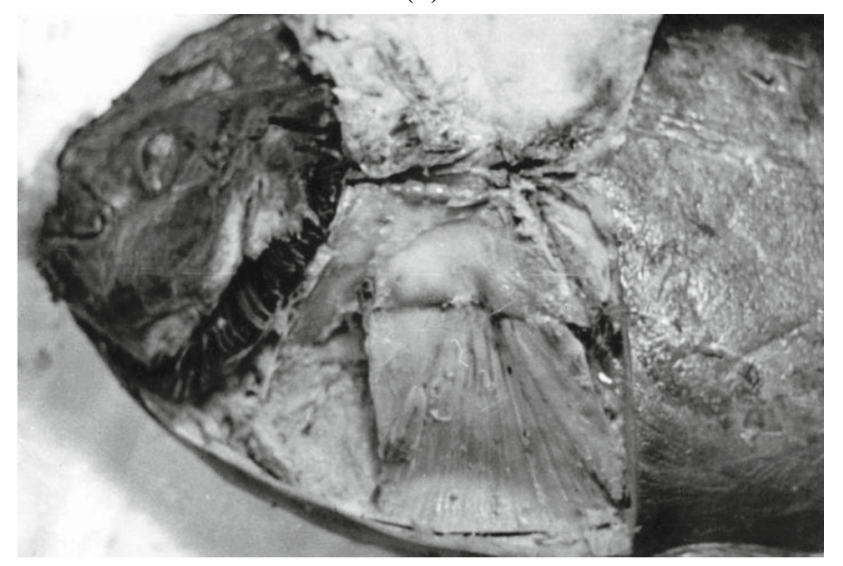

(b)

(c)

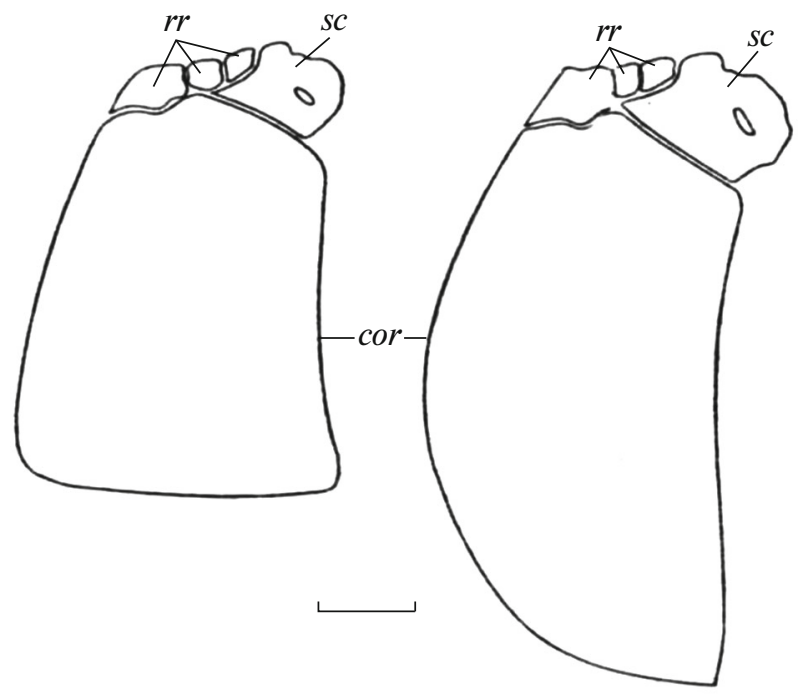

Fig. 5. (a) Prepared shoulder girdle of Lampris immaculatus with SL $820 \mathrm{~mm}$ from the ZMMU, no. P-16034 and bones of the shoulder girdle of representatives of the two opah subgenera: (b) L. (Paralampris) immaculatus and (c) Lampris spp. (according to Parin and Kukuev, 1983); $r r$, radialia, sc, scapula, cor, coracoideum. Scale: $1 \mathrm{~cm}$.

D i a g n o s is. Body in the form of an elongated ellipse, terete, with rounded belly. Ventral fins far beyond vertical of pectoral fin base; $P-V 16-24 \% S L$. External plate of caracoid in shoulder girdle skeleton almost rectangular (Figs. 5a and 5b). Light spots on body absent in all age groups.

The subgenus includes only one species, $L$. (P.) immaculatus, with the notal-Subantarctic type of range.

E ty mology. The name of the genus, Paralampris, indicates its affinity to the genus Lampris; the grammatical gender is masculine.

\section{ACKNOWLEDGMENTS}

I am grateful to E.M. Gerber and G.K. Miloradov (Zaprybpromrazvedka), I.I. Konovalenko (AtlantNIRO), and A.R. Boltachev for providing the collection material, as well as to A.V. Remeslo (AtlantNIRO) for providing the pictures of opahs, which were made during expeditions. I am particularly grateful to Nikolai Vasil'evich Parin for the joint work on restoring the validity of $L$. immaculatus.

\section{COMPLIANCE WITH ETHICAL STANDARDS}

Conflict of interests. The authors declare that they have no conflicts of interest.

Statement on the welfare of animals. All applicable international, national, and/or institutional guidelines for the care and use of animals were followed.

\section{OPEN ACCESS}

This article is licensed under a Creative Commons Attribution 4.0 International License, which permits use, sharing, adaptation, distribution and reproduction in any medium or 
format, as long as you give appropriate credit to the original author(s) and the source, provide a link to the Creative Commons license, and indicate if changes were made. The images or other third party material in this article are included in the article's Creative Commons license, unless indicated otherwise in a credit line to the material. If material is not included in the article's Creative Commons license and your intended use is not permitted by statutory regulation or exceeds the permitted use, you will need to obtain permission directly from the copyright holder. To view a copy of this license, visit http://creativecommons.org/licenses/by/4.0/.

\section{REFERENCES}

Agafonova, T.B. and Kukuev, E.I., New data on distribution of Cubiceps gracilis Lowe, 1843, Vopr. Ikhtiol., 1990, vol. 30, no. 6, pp. 1028-1031.

Andriyashev, A.P., Problem of geographic and bathymetric distribution of primitive forms within the group areal, Biol. Morya (Vladivostok), 1988, no. 5, pp. 3-9.

Collette, B. and Nauen, C., FAO Species Catalogue, Vol. 2: Scombrids of the World. An Annotated and Illustrated Catalogue of Tunas, Mackerels, Bonitos and Related Species Known to Sate, FAO Fish Synopsis no. 125, Rome: UN Food Agric. Org., 1983.

Hyde, J., Underkoffler, K., and Sundberg, M., DNA barcoding provides support for a cryptic species complex within the globally distributed and fishery important opah (Lampris guttatus), Mol. Ecol. Res., 2014, vol. 14, pp. 12391247.

https://doi.org/10.1111/1755-0998.12268

Kukuev, E.I., Ikhtiologicheskie ocherki o rybakh izvestnykh $i$ maloizvestnykh (Ichthyologic Articles on Known and Unknown Fishes), Kaliningrad: Atl. Nauchno-Issled. Inst. Rybn. Khoz. Okeanogr., 2014a.

Kukuev, E.I., Formation of extratropical (moderately coldwater and bipolar) ranges of species of mesopelagic fish of high-latitude areas of the world ocean, J. Ichthyol., 2014b, vol. 54 , no. 10 , pp. $790-807$.

https://doi.org/10.1134/S0032945214100099
Kukuev, E.I. and Nigmatullin, Ch.M., Functional morphology, behavior, and biotope distribution of fishes of the genus Lampris (Lampridae), Materiali I Mizhnarodnoi ikhtiologichnoi naukovo-praktichnoi konferentsii "Suchasni problemi teoretichnoi i praktichnoi ikhtiologii," Kaniv, Tezi (Proc. I Int. Ichthyol. Sci.-Pract. Conf. "Modern Problems of Theoretical and Practical Ichthyology," Kanev, Abstracts of Papers), Sevastopol, 2008, pp. 92-94.

Linberg, G.U., Opredelitel' $i$ kharakteristika semeistv ryb mirovoi fuany (Guide for Identification and Characteristics of Fish Families in the World Fauna), Leningrad: Nauka, 1971.

Nel'son, D.S., Ryby Mirovoi fauny (Fishes of the World Fauna), Moscow: Librokom, 2009.

Oelschlager, H.A., Das Jugendstadium von Lampris guttatus (Brunnich, 1788) (Osteichthyes, Allotriognathi), ein Beitrag zur Kenntnis seiner Entwicklung, Arch. Fischereiwiss., 1974, vol. 25, pp. 1-55.

Palmer, G., Lampridae, in Check-List of the Fishes of the North-Eastern Atlantic and of the Mediterranean, Paris: UNESCO, 1973.

Parin, N.V., A problem of "species groups" in epi- and mesopelagic fishes by example of families Exocoetidae and Astronesthidae, Materialy Vserossiiskoi konferentsii "Sovremennye problemy sistematiki ryb," Tezisy dokladov (Proc. All-Russ. Conf. "Modern Problems in Fish Taxonomy," Abstracts of Papers), St. Petersburg, 1988, p. 47.

Parin, N.V. and Kukuev, E.I., Recovery of validity of Lampris immaculatus (Gilchrist) and geographic distribution of Lampridae, Vopr. Ikhtiol., 1983, vol. 23, no. 1, pp. 3-14.

Trunov, I.A. and Kukuev, E.I. New data on fish of families Trachipteridae and Regalecidae (Trachipteroidei) in the Argentine Basin (Southwest Atlantic Ocean), Vopr. Ikhtiol., 2005, vol. 45, no. 2, pp. 188-193.

Underkoffler, K.E., Luers, M.A., Hyde, J.R., and Craig, M.T., A taxonomic review of Lampris guttatus (Brünnich 1788) (Lampridiformes; Lampridae) with descriptions of three new species, Zootaxa, 2018, vol. 4413, no. 3, pp. 551-565. https://doi.org/10.11646/zootaxa.4413.3.9

Translated by D. Zabolotny 